\title{
Creating a School Gardens Program in the Challenging Environment of Las Vegas, Nevada
}

\author{
Angela M. O'Callaghan ${ }^{1}$
}

\begin{abstract}
ADDITIONAL INDEX WORDs. desert horticulture, population, survey, teacher training
SUMMARY. An important element of the social horticulture program at the University of Nevada Cooperative Extension has been the creation of school gardens to enhance educational efforts for children in Las Vegas. Since 2002, a variety of methods has been employed to train teachers and administrators in using gardens, and this has resulted in establishment of successful gardening programs. Southern Nevada has experienced a $400 \%$ population increase in 25 years. Results of surveys of area stakeholders between 2000 and 2002, Clark County elementary school staff in 2001, and Clark County school principals in 2004, indicate a desire to incorporate gardens in schools, but concerns about establishing and maintaining them persist. Furthermore, apprehension about trying to garden under challenging climatic conditions characteristic of the Mojave Desert is expressed frequently, as is hesitation about using gardens to enhance the school curriculum in at-risk schools. When offered training in use of gardens, however, a majority of principals surveyed responded positively. They also expressed interest in tracking the educational and social impacts of gardens on students and faculty. This article reports on results of community stakeholder meetings and surveys of Clark County schools, as well as the methods that are being used to create a school gardens program in the most rapidly growing metropolis in the United States.
\end{abstract}

$\mathrm{H}$ orticulture has been found to be important in a range of human situations-prisons, hospitals, communities (Simson and Straus, 1998)—and most especially in schools (DeMarco et al., 1999). University of Nevada Cooperative Extension (UNCE), in cooperation with teachers, governmental and private agencies, and community groups, has instituted programs to create gardens at schools in southern Nevada. Faculty, staff, and volunteers currently work with schools and child care centers throughout Clark County, Nev. UNCE teaches, coaches, and cooperates with teachers, staff, and students in instituting and maintaining these as learning environments to complement traditional classrooms.

In 1940 , the population of Las Vegas was 8422. By 1980 it had reached 250,000 and estimates for 2005 indicate the population will be 2 million; a rate of about 4000 new residents per month (City of Las Vegas, 2004). Twenty-six percent of the

${ }^{1}$ Area Specialist, Assistant Professor, University of Nevada Cooperative Extension, 2345 Red Rock St., Las Vegas, NV 89146; phone: 702-257-5581; e-mail: ocallaghana@unce.unr.edu population is under 18 years old (U.S. Census Bureau, 2003). With more than 280,000 students, the Clark County School District (CCSD) is now the fifth largest in the U.S. Such rapid growth necessitates opening several elementary, middle and high schools each year. In Fall 2004 alone, seven elementary schools, three middle schools, and three high schools were opened. Many CCSD pupils are from lower income families, with $35.6 \%$ of them being eligible for free or reduced-cost lunch (CCSD, 2004). They often arrive from areas with environments very different from the Las Vegas area, which is located in the Mojave Desert. Simmons [1993 (cited in Dobbs et al., 1998)] noted that teachers often hesitate to use outdoor settings in education as they do not believe they know how to use them effectively. This could be especially problematic in a district where there is a $35.5 \%$ pupil transience rate. The Nevada Department of Education lists Clark County schools (elementary, middle, and high) overall as "in need of improvement" (Nevada Dept. of Education, 2004), which could make administrators reluctant to try anything that would appear experimental. Furthermore, many Clark County teachers also come from regions with climates and soils unlike those of southern Nevada. In all, these create a situation quite different from other areas, as in Dobbs et al. (1998), where teachers responding to a gardening survey were mainly experienced gardeners.

Even people who are experienced in gardening in other parts of the country frequently find it very difficult to garden under Mojave Desert conditions. Driest of the North American deserts, an average of 4.3 inches (109.2 $\mathrm{mm}$ ) of rain falls annually in the Mojave Desert [Southern Nevada Water Authority (SNWA), 2003]. Light intensity is high; the area experiences, on average, $85 \%$ of possible sunlight. Each year approximately $133 \mathrm{~d}$ have daytime air temperatures over $90{ }^{\circ} \mathrm{F}$ $\left(32.2^{\circ} \mathrm{C}\right)$ and over $72 \mathrm{~d}$ where daytime temperatures exceed $100^{\circ} \mathrm{F}\left(37.8^{\circ} \mathrm{C}\right)$ (National Weather Service Forecast Office, 2004). Soils tend to be high in $\mathrm{pH}$, boron, and salinity, and low in organic matter; hence native vegetation differs from most of the U.S.

Clark County has one of the lowest rates of recycling/composting in the U.S. (U.S. Environmental Protection Agency, 2002). As with children in many urban areas, there is a lack of connection between themselves and the natural environment, whether it is the sources of their food or the native plants and animals in wildlands outside of cities. It is important to provide training and leadership in these topics to the area's youth (Disinger, 2001). Educators throughout the U.S. are seeking alternative teaching sites and modalities. Interest in using gardens for educational purposes has grown over the past decade (Guy et al., 1996). Skelly and Bradley (2000) noted that not only do gardens need to be installed, but also teachers need to learn how to incorporate them into their lessons. Some school districts in the U.S. have successfully incorporated gardens on a wide scale (DeMarco et al., 1999), but this has not yet been the case in southern Nevada.

This article reports on efforts-focus groups, administrator surveys, and teacher training - to create a school gardens program in the Las Vegas area and empower teachers.

\section{Materials and methods}

Because southern Nevada has such a newly expanded population, several separate methods were employed as 
the school gardens program was being started. The first steps concentrated on gaining insight into community preferences and then on contacting schools where gardens might be useful as outdoor classrooms. These included focus groups of community leaders to determine what horticultural efforts would be useful to the community, followed by surveys of school principals. Training of school personnel was done using small school-based staff development days, lessons from the Master Gardener curriculum and the Food, Land and People (FLP) curriculum as well as the Las Vegas Farm Festival. All of these were geared at improving teacher skills and familiarity with horticulture, agriculture, and natural resource protection.

STAKEHOLDER FOCUS GROUPS. In UNCE stakeholder input sessions, community leaders were recruited by county extension educators to advise UNCE administration on determining which topic areas should be given priority by cooperative extension. These leaders participated in a series of meetings held throughout Nevada between 2000 and 2002 .

MaIl SURVeY OF PRINCIPALS (2001). A brief (10 short-answer questions) anonymous questionnaire was mailed during the first week of Dec. 2001 to the principals of all 169 elementary schools, as listed in the CCSD directory. Questions were based on input from conversations with personnel from schools with gardens. The questionnaire was designed to be as brief as possible, as the upcoming holiday break made it a less than ideal time for a school survey. Despite its timing, 65 questionnaires $(38.5 \%)$ were returned by the end of that month.

Phone SURVeY OF SCHOOL PRINCIPALS (2004). School principals were surveyed by telephone before the start of the Fall 2004 school year to elicit information on school gardens and garden-related programs. Twenty-one schools were surveyed at random from among schools that had communicated with UNCE or had worked with its staff or volunteers concerning gardens. These included three early childhood centers, 14 elementary schools, three middle schools, and one high school. Contact persons included principals, assistant principals, and interested faculty. The survey was designed using input from personnel in schools where gardens were being used successfully.

ACTIVITIES FOR TEACHERS AND schools. Between 2002 and 2004, a variety of techniques was used to train school personnel in the creation, maintenance, and use of school gardens. UNCE held mini-trainings at 15 individual schools during this period, using exercises based on the FLP and Junior Master Gardener (JMG) curricula, as well as locally developed materials. These materials included UNCE fact sheets and special pub-

lications as well as citations of other resources that could assist teachers and administrators in developing a school garden program.

Much program activity is done in collaboration with members of interested groups. These groups include: Agriculture in the Classroom (state and county committees), CCSD, Dairy Council of Utah/Nevada, the Gardens at the Las Vegas Springs Preserve, and the Clark County Health District.

Junior Master Gardener TRAINING. UNCE hosted JMG train-

Table 1. Survey of Clark County, Nev., elementary school principals in Dec. 2001 concerning the presence and usefulness of school gardens and problems which they may have encountered.

Responses from principals of schools with gardens $(n=24)$

Responses (no.)

Yes, all teachers Yes, some teachers No teachers

a) Do teachers in your school use this garden as a teaching tool?

$0 \quad 22$

0

If teachers had training or guidance, would they use the garden for teaching? 5

5

Are there any problems with your garden now? Yes No No answer 14

8 2

b) What would you call the largest problem (now or in the past)? (n = 23)

\begin{tabular}{lrr}
\cline { 2 - 3 } Upkeep & & \\
Weeds & 6 & 26 \\
Watering & 3 & 13 \\
Insects & 3 & 13 \\
Heat & 2 & 9 \\
Teacher interest & 2 & 9 \\
Lack of money & 2 & 9 \\
Vandalism & 2 & 9 \\
Getting started & 3 & 13
\end{tabular}

c) Responses from principals of schools without gardens when asked about establishing and using gardens $(n=33)$

$\frac{\text { Responses (no.) }}{\text { Yes No }}$

Would you and your school be interested in having a garden?

Would you want teachers in your school to use it as part of their curricula?

$32 \quad 1$

Would teachers want/need training to use it? All (3) Some (29) None (0)

d) The major reason(s) school does not have a garden (some gave more than one response) Responses (no.) Proportion of responses (\%)

Lack of interest

Lack of money

Never thought about it

Fear of vandalism

New school (not yet established)

$\begin{array}{rr}2 & 6 \\ 29 & 88 \\ 5 & 15 \\ 5 & 15 \\ 5 & 15\end{array}$

If your school had a garden in the past but no longer does, what would you say is the biggest reason it was stopped? Interested teacher left $5(15 \%)$

${ }^{2}$ Percentages not cumulative. 
ing in Jan. 2003, which was attended by 25 teachers and principals from the CCSD.

Las Vegas Farm Festival. This is an annual event attended by as many as 8000 elementary school children. It is staffed by Master Gardeners and other volunteers from throughout Nevada. Evaluation forms were distributed to 324 teachers who attended the 2003 Farm Festival with their classes.

Food, Land and People. In July 2004, a professional development training taught use of the FLP curriculum to 35 elementary, middle, and high school teachers from throughout Clark County. This curriculum has been aligned to Nevada state standards in order to assist teachers in using the materials. Those who attended evaluated the program for quality of the presentations as well as for classroom applicability.

\section{Results}

Focus GROUP RESUlTs. Nevada stakeholders viewed school gardens as highly important. The need for youth and career information in horticulture was explicitly mentioned by more than $50 \%$ of communities (UNCE, 2004).

Results of the Dec. 2001 SURVEY OF ELEMENTARY SCHOOL PRINCIPALS. These are presented in Table 1. Most of the principals ( $88 \%$ of those in schools without gardens, and $83 \%$ of those with gardens) indicated a desire for gardens and for teacher training in their use. All of the principals of schools with gardens stated that teachers used the gardens at least some of the time. The greatest barriers to establishing gardens were concerns over cost and potential vandalism. Once gardens were established, however, the major problem listed was the labor involved in maintenance. The most commonly cited reason for garden failure was none of the above, but rather that the individual (usually a teacher) who was the driving force behind the garden left the school. This emphasized the need for participation by many members of the school community.

Since those 65 principals returned their surveys in 2001 , more gardens and horticultural activities have been started in the Las Vegas area. These activities range from seed planting within classrooms, to raised vegetable beds, to native Mojave Desert plant demonstrations. Several schools have also incorporated composting as a means of introducing recycling to their students. UNCE staff and Master Gardeners have been instrumental in many of these efforts.

The responses gained from the focus groups and the mail survey of school principals served as the steps toward creating the program.

RESUlTS OF 2004 SURVEY OF SCHOOL PRINCIPALS. Contact persons at 21 schools were reached before the start of the Fall 2004 academic year. Among schools that currently have gardens ( $\mathrm{n}$ $=12$ ), longevity ranged from just a few months to 13 years. Contacts at 20 of the schools indicated that there was eagerness to build or expand gardens or increase the uses for the garden. They also expressed enthusiasm to have regular involvement of a Master Gardener who could serve as a mentor to teachers and students. One school had had a garden, but negative experiences (vandalism) left the administration reluctant to reestablish one. While none of the schools had measured the effects of the gardens on pupils or the school environment as of the time of the survey, all perceived a net benefit from gardens. Results of the survey appear in Table 2.

A community-based instructor has been hired to coordinate the school gardens program. After surveying the principals in the 2004 survey, this person meets with principals and teachers to provide initial and ongoing training on garden use to teachers and students. In addition, she coordinates the Master Gardeners who volunteer at these school gardens. The school gardens program coordinator works closely

Table 2. Results of 2004 telephone survey of 20 principals of Clark County, Nev., schools that had contact with University of Nevada Cooperative Extension (UNCE) between 2001 and 2003 concerning school gardens.

\begin{tabular}{|c|c|c|}
\hline & $\begin{array}{l}\text { Respondents } \\
\text { (no.) }\end{array}$ & $\begin{array}{l}\text { Proportion of } \\
\text { respondents }(\%)\end{array}$ \\
\hline \multicolumn{3}{|l|}{ Results from all 20 schools } \\
\hline Want UNCE training & 20 & 100 \\
\hline Want Master Gardener mentoring & 20 & 100 \\
\hline \multicolumn{3}{|c|}{$\begin{array}{l}\text { Primary goal of garden } \\
\text { (some respondents gave multiple answers) }\end{array}$} \\
\hline Educational & 17 & 85 \\
\hline Beautification & 7 & 35 \\
\hline Conservation & 5 & 20 \\
\hline Sense of ownership & 3 & 15 \\
\hline Learning cause and effect & 3 & 15 \\
\hline Enjoyment & 2 & 10 \\
\hline \multicolumn{3}{|c|}{ Results from schools with gardens $(\mathrm{n}=12)$} \\
\hline \multicolumn{3}{|c|}{$\begin{array}{l}\text { Proportion saying that garden is, or would be, } \\
\text { a net benefit }(\%)\end{array}$} \\
\hline \multicolumn{3}{|c|}{ Garden funding source } \\
\hline Grant & 5 & 42 \\
\hline School personnel donated & 6 & 50 \\
\hline Unknown source & 1 & 8 \\
\hline \multicolumn{3}{|l|}{ Garden use } \\
\hline Use with a preset curriculum & 4 & 33 \\
\hline Teachers use garden daily & 8 & 66 \\
\hline Teachers use garden weekly & 2 & 17 \\
\hline Parents are involved in garden & 5 & 42 \\
\hline \multicolumn{3}{|l|}{ Maintenance } \\
\hline Teachers, students & 11 & 92 \\
\hline School custodian & 1 & 8 \\
\hline \multicolumn{3}{|c|}{ What would principal change about garden? } \\
\hline "New kinds of plants and flowers" & 3 & 25 \\
\hline Increase usage & 3 & 25 \\
\hline Location & 2 & 17 \\
\hline Continuity & 1 & 8 \\
\hline Increase size & 1 & 8 \\
\hline Weed control & 1 & 8 \\
\hline Add desert tortoise habitat & 1 & 8 \\
\hline
\end{tabular}


with schools interested in establishing more JMG projects and in using the FLP curriculum. Master Gardeners are joining in school garden committees, the Las Vegas Farm Festival planning team, and leading plant-related activities at schools.

Junior Master Gardener TRAINING. As a result of the Jan. 2003 JMG training, the Gardens at the Las Vegas Springs Preserve and one elementary school have each established certified JMG gardens. One Master Gardener attendee has taken on the task of correlating the JMG curriculum with Nevada state standards for science, math, language arts and social studies.

Las Vegas farm Festival. Responses were received from $29 \%(\mathrm{n}=$ 94) of the teachers who attended the 2003 Las Vegas Farm Festival. Results are shown in Table 3.

Food, Land and People. The professional development training held over 3 days in July 2004 used the FLP curriculum. Evaluation results are presented in Table 4. The overall satisfaction rating using a Likert-type scale was $4.34(\mathrm{n}=39)$.

\section{Discussion}

The population of the Las Vegas area continues to rise rapidly as people arrive from other parts of the U.S. Horticultural activities can offer many new school-age residents the opportunity to establish "roots" and connect with their natural environment. Students can be involved in seeing how native plants survive a harsh environment as well as learning about edible plant species from other parts of the world. For many children, school gardens offer their first encounters with fruits or vegetables that have not been processed.

The results of the surveys con-

Table 3. Responses from Clark County, Nev., teachers who brought their classes (kindergarten through fifth grade) to 2003 Las Vegas Farm Festival when asked to evaluate the experience $(n=94)$.

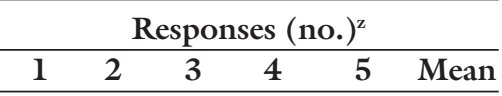

Compare Farm Festival with other away from school activities:

$\begin{array}{lllll}1 & 15 & 28 & 48 & 4.30\end{array}$

In your judgment, how much did your students enjoy the Farm Festival?

$\begin{array}{lllll}0 & 14 & 27 & 52 & 4.38\end{array}$

Our basic purpose was to help students understand that agriculture is part of their everyday lives. How well did we accomplish that goal? $\quad \begin{array}{lllllll}11 & 4 & 27 & 33 & 27 & 3.60\end{array}$ ${ }^{2} 1=$ lowest; $3=$ above average; 5 = highest.

Table 4. Evaluation results of professional development training for Clark County, Nev., teachers held in July 2004. Responses to question: "On a scale of 1 to 5 , with 5 being the highest, how applicable was this material to your classroom?" $(\mathrm{n}=39)$

\begin{tabular}{lc}
\hline Topic & $\begin{array}{c}\text { Applicable to classroom } \\
\text { (mean on 1-5 scale) }\end{array}$ \\
\hline What is Food, Land and People (FLP)? & 4.13 \\
Nevada's agriculture & 4.77 \\
Nevada content standards and resources & 4.44 \\
Farm tour & 4.42 \\
A walk through FLP & 4.24 \\
Using journaling & 4.31 \\
Building theme units & 3.84 \\
Specific FLP workshops & \\
"Backyard conservation” & 4.13 \\
"Cows to condos" & 4.08 \\
“Gifts from the sun” & 3.97 \\
"Don't use it all up" & 4.21 \\
"Fiber to fashion” & 4.37 \\
"Breads around the world” & 4.87 \\
\hline
\end{tabular}

ducted in southern Nevada concur with those of DeMarco et al. (1999) that the most successful school gardens and gardening programs appear to be those schools where teachers and administration are most involved. Schools have reported that money is not the most critical issue. While the price of establishing a garden is often feared as being prohibitive, once gardens are in place, principals do not report that they are a financial burden. Despite misgivings about practical aspects of school gardening, there is an overall positive reaction to establishing them, particularly when there will be training and support for the project.

As this program continues to expand along with southern Nevada's population, it will be essential that teachers be trained as both educators and gardeners. Principals surveyed have indicated that this will increase use of school gardens. By providing training to them, the empowerment of teachers found by Dobbs et al. (1998) can hold as true in the Mojave Desert as it does in other areas of the country.

\section{Literature cited}

City of Las Vegas. 2004. The history of Las Vegas. 13 Aug. 2004. <http://www.ci.lasvegas.nv.us/history/default.htm>.

Clark County School District. 2004. 20032004 District accountability comprehensive report. 15 Aug. 2004. <http://www. ccsd.net/schools/acc_reports/scool_acc. phtml>.

DeMarco, L.W., D. Relf, and A. McDaniel. 1999. Integrating gardening into the elementary school curriculum. HortTechnology 9:276-281.

Disinger, J.F. 2001. K-12 education and the environment: Perspectives, expectations, and practice. J. Environ. Educ. 33:4-11.

Dobbs, K., D. Relf, and A. McDaniel. 1998. Survey on the needs of elementary education teachers to enhance the use of horticulture or gardening in the classroom. HortTechnology 8:370-373.

Guy, L., C. Cromell, and L. Bradley. 1996. Success with school gardens: How to create a learning oasis in the desert. Arizona Master Gardener Press, Phoenix.

National Weather Service Forecast Office. 2004. Climate of Las Vegas, Nevada. 12 Aug. 2004. <http://www.wrh.noaa.gov/ vef/climate/index.php>. 
Nevada Department of Education. 2004. Nevada annual reports of accountability. 12 Aug. 2004. <http://www.nevadareportcard.com $/>$.

Simson, S.P. and M.C. Straus (eds.). 1998. Horticulture as therapy: Principles and practice. Food Products Press, New York.

Skelly, S.M. and J.C. Bradley. 2000. The importance of school gardens as perceived by Florida elementary school teachers. HortTechnology 10:229-231.

Southern Nevada Water Authority. 2003. Drought handbook. 17 May 2004. <http://www.snwa.com/assets/pdf/ drought_handbook.pdf>.

University of Nevada Cooperative Extension. 2004. University of Nevada Cooperative Extension 2000-2002 community meetings. 17 Oct. 2004. <http://www. unce.unr.edu/Gateway/gateway.htm>.

U.S. Census Bureau 2003. United States census 2000. 17 Oct. 2004. <http:/ /www. census.gov/main/www/cen2000.html>.

U.S. Environmental Protection Agency. 2002. Assessing the potential for resource management in Clark County, Nevada. 22 Jan 2004. <http://www.epa.gov/region09/waste/solid/nevadarm.html>. 